A. Penaki ${ }^{1}$, Deputy Manager of laboratory E-mail: annarevenko28041987@gmail.com A. Borta ${ }^{2}$, PhD Tech. Science, Associate Professor, E-mail: borta.alla@ukr.net https://orcid.org/0000-0001-9790-4732, ResearcherID: F-9893-2016

${ }^{1}$ LLC "MV Cargo", Odessa region, (Ukraine)

${ }^{2}$ Department of grain storage technology, Odessa National Academy of Food Technologies, 112, Kanatna Str., 65039, Odessa, Ukraine

\title{
THE STUDY OF QUALITY INDICATORS AND FRACTIONAL COMPOSITION OF WHEAT GRAIN PROTEIN OF SOUTHERN REGIONS OF UKRAINE
}

\begin{abstract}
The results of studies of the quality of food and non-food grain of wheat from the southern regions of Ukraine in 2016 harvest are presented. The indicators of the quality of wheat grain were determined, the uniformity of their distribution in different classes of wheat was assessed, the content of protein fractions of the gluten complex and the molecular weights of individual protein structures were determined. It was found that the studied 13 samples of wheat grain had the following quality indicators: moisture content $9.4 \ldots 13.5 \%$, bulk density $731 \ldots 814 \mathrm{~g} / \mathrm{l}$, protein content $10.1 \ldots 13.2 \%$, gluten content $16.4 \ldots 25.6 \%$, gluten quality $50 \ldots 110$ units of the IDK device, falling number $311 \ldots 493 \mathrm{~s}$, grain admixture $1.2 \ldots 10.5 \%$, grains damaged by a wheat bug, $0.1 \ldots 10.1 \%$. It was noted that the bulk density of all samples of wheat of 2 ... 6 classes exceeded the standard values in each class. In terms of protein content, 2 from 3 samples of class 5 wheat and 1 from 2 samples of 6 class exceeded the standard value of class 3 wheat $(\geq 11.0 \%)$. The same was observed for these samples and for the gluten content $(\geq 18 \%)$. Almost all grain samples, except for 2 samples of the 5 th class and 2 samples of the 6th class, met the requirements of wheat of the 2 nd class (45 ... 100 units device VDK). The falling number of all samples was high and significantly exceeded the normalized value $(180 \mathrm{~s})$, even for class 2 wheat. It was found that the uniformity of the distribution of individual quality indicators in different classes of wheat grain by the coefficient of variation is not the same. Such indicators of grain quality as moisture content, bulk density and protein content in different samples of the south of Ukraine in 2016 harvest fluctuated weakly $(V \leq 10 \%)$, in terms of the amount of gluten and the falling number fluctuations were average

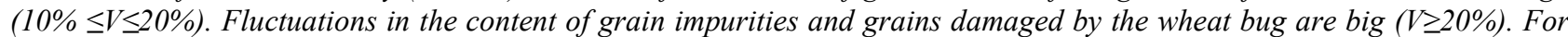
the last indicator, fluctuations relative to the average are very large and exceed $120 \%$. This indicates that in different areas where wheat was grown, the infestation by the wheat bug was very different. It was shown that regardless of the total amount of protein determined by the Infratec FOSS express analyzer, four protein fractions of the gluten complex (albumins, globulins, gliadins and glutenins) are present in all grain classes, and the molecular weights of the protein structures of the main fractions are within small limits, which are in $\mathrm{kDa}$ - for albumins and globulins 20...30, gliadins $27 . .100$ and glutenins 30...35. It was noted that in the varietal wheat "Chernobrova" albumins and globulins have a slightly higher molecular weight $(30 \ldots 40 \mathrm{kDa})$ than in non-varietal wheat.
\end{abstract}

Key words: grain and wheat classes, indicators of wheat quality, proteins of the gluten complex, gel electrophoresis, fractional composition of proteins, molecular weights of protein structures.

\section{Formulation of the problem}

Since ancient times, grain farming has been the basis of agricultural production, and the level of its development is one of the main indicators of the country's economic development, which directly affects the material well-being of the population. Wheat takes the leading place among grain crops, the main food product of which is bread - people consume daily. The quality of wheat grain processing products depends on many factors like the quality of the harvested crop, its post-harvest ripening, processing, reliable storage, and, of course, the technology of its processing.

The stability of the quality of wheat grain is one of the most difficult and least predictable indicators, because quality indicators (protein content, content and quality of gluten, $\alpha$-amylase activity by falling number) can fluctuate and change depending on the variety, conditions and region of cultivation, storage conditions etc... However, the main role in determining the class and quality of grain belongs to proteins, the content and quality of which depend on many factors. It is the content of the mass fraction of protein that underlies the classification of wheat grains in many countries of the world.

The protein content of food is usually determined by the amount of nitrogen using the Kjeldahl method. It (since 1983) has been repeatedly modified using various catalysts and mineralization conditions. On the basis of this method, automatic analyzers "Kjelfos" were created. The Kjeldahl method has certain drawbacks, but it remains unified and is included in DSTU. Its essence lies in the mineralization of the product and the determination of the nitrogen content in it. A factor of 6.25 is used to convert the amount of nitrogen to the protein content. It is accepted because most proteins contain $16 \%$ nitrogen $(100 / 6.25=16)$. But it is more correct to use coefficients corresponding to the actual protein content: for wheat, rye, barley, oats, and sunflower - 5.7; for soybeans - 5.8; for corn and meat -6.25 ; for milk - 6.38. There are other, rather expensive, methods, such as the Dumas method, neutron activation with phenolate hypochloride, on the device 
«Technikon». The principle of the Dumas method is the decomposition of an organic compound in an atmosphere of carbon dioxide into a gaseous state, followed by measurement of the volume of nitrogen $[1,2]$.

The method of infrared spectroscopy, which is based on the absorption of light with a certain wavelength by proteins and measuring the intensity of its reflection in express analysis devices, has become widespread for determining the protein content, in particular, the method of NIR spectrometry - the method of infrared spectrometry in the near range $[1,3]$.

Recently, a deeper study of not only the protein content, but also the components of wheat protein have become important, because post-harvest ripening of wheat grain and its storage conditions cause changes in the ratio of individual fractions of proteins and its structure. To characterize protein substances, data on the amino acid composition is most often used, which makes it possible to assess the nutritional value of proteins. In various technological processes of grain processing, the solubility of proteins and their rheological properties, caused by changes in the molecular weights of proteins and their individual fractions, change significantly. With a change in the protein structure, the genetic properties of varieties also change, and accordingly, the yield and quality of the grown crop change [4].

It is known that cereal proteins are unevenly distributed between the anatomical parts of the grain. Wheat proteins consist of four main groups depending on their ability to dissolve in water - albumins, globulins, gliadins and glutenins. A significant amount of protein is contained in the endosperm $(65 \ldots 75 \%)$ and much less in the aleurone layer (up to $15.5 \%$ ) and the embryo (up to $22 \%$ ). Embryo and aleurone layer proteins are represented mainly by albumins and globulins, which perform a catalytic function during grain germination (enzymes), and endosperm proteins - by albumins, globulins, prolamines and glutelins $[4,5]$.

Gliadins and glutenins belong to the class of storage or gluten proteins. The content of albumins and globulins is $15 \ldots 20 \%$, gliadins $-40 \ldots 50 \%$, glutenins $35 . . .40 \%$ of the total protein content [6].

About $80 \ldots 85 \%$ of the total protein content in grain is gluten proteins. Gliadin affects such important dough qualities as viscosity and extensibility, gluteninselasticity and firmness [7].

In addition to gluten, wheat proteins include two more proteins-albumin $(15 \ldots 20 \%)$ and globulins $(15 \ldots 20 \%)$, which are responsible for enzymatic activity.

One of the most accurate methods for studying the structure of a protein is its fractionation into constituent fractions using electrophoresis. This method is unique in a certain way, since it makes it possible not only to decompose the protein into its constituent parts, but also to investigate the molecular weight of each separately taken protein fraction [8].

Electrophoresis is an electrokinetic phenomenon of displacement of particles of a dispersed phase or protein solutions in a liquid medium under the action of an external electric field. With the help of this phenomenon, it is possible to separate proteins into fractions that differ in their molecular weight under the action of an electric current.
Gel electrophoresis is an analytical chemistry and molecular biology technique for separating different kinds of molecules. The mixture of molecules is passed through a gel, which is a molecular sieve that allows small molecules to pass more easily than large ones. The driving force is set by the electric field, so the molecules must be charged [8]

Electrophoresis of proteins in polyacrylamide gel is based on the unequal electrophoretic mobility of individual protein fractions in accordance with their electrophoretic mobility (a function of the length of the polypeptide unit or molecular weight, as well as the confinement of the protein molecule, post-translational modifications, and other factors).

In the literature, there are significant fluctuations in grain quality indicators depending on the harvest year, the region of cultivation, agrotechnological, climatic and many other factors [9-12]. Therefore, a further in-depth study of the quality of wheat grain, an assessment of the possibility of forming batches of different target purposes from it, will make it possible to better assess the grain potential of various regions of our country and find ways of its rational use.

\section{The purpose and objectives of the study}

The aim of the work was to determine the quality indicators of wheat grain from the southern regions of Ukraine, to determine the content of protein, its protein by solubility fractions and their molecular weights in grain of different classes.

To achieve the aim, it was necessary to solve the following tasks:

- to determine the indicators of the quality of wheat grain from the southern regions of Ukraine;

- to assess the uniformity of the distribution of individual quality indicators in different classes of wheat grain;

- to determine the content and molecular weights of each of the protein fractions of wheat gluten of different classes.

\section{Materials and methods of research}

The studies used grain samples of food and nonfood wheat of the harvest of 2016, selected at 13 grainprocessing enterprises in the southern regions of Ukraine, of which 2 classes -4 samples, 3 classes -4 samples, 5 classes - 3 samples and 6 classes -2 samples. Among the grains of wheat of the 2nd class, one sample of the variety "Chernobrova" (No. 4) was used.

In the initial samples of wheat grain, such quality indicators were determined as moisture content, bulk density, protein content, quantity and quality of gluten, falling number, grain impurities and grains damaged by a wheat bug.

Moisture and protein content were determined by infrared spectroscopy on a FOSS Infratec instrument (DSTU 4117: 2007); the content of gluten and its quality manually (GOST 13586.1-68) falling number by the standard Perten-Hagberg method on the Perten Falling Number device (DSTU ISO 3093: 2009), bulk density by volumetric weight method on a liter purka with a falling weight (GOST 10840-2017, IDT) the content of grain impurities and the content of grains damaged by the 
wheat bug, by the visual method (GOST 30483-97, GOST 3768: 2010).

Statistical characteristics of quality indicators arithmetic mean, standard deviation, coefficient of variation and correlation coefficient were determined in MS Excel using known expressions [13-15]:

$$
\begin{gathered}
\bar{Q}_{j}=\frac{\sum_{i=1}^{n} Q_{i, j}}{n} ; \quad S_{j}=\frac{\sum_{i=1}^{n}\left(Q_{i, j}-\bar{Q}_{j}\right)}{n-1} ; \\
V_{j}=\frac{100 \cdot S_{j}}{\bar{Q}_{j}}: \quad R=\frac{\frac{1}{n} \sum_{i=1}^{n} Q_{i, j} Q_{i, k}-\bar{Q}_{i, j} \bar{Q}_{i, k}}{S_{j} S_{k}},
\end{gathered}
$$

where $\bar{Q}_{j}-$ the arithmetic mean of the $\mathrm{j}$-th quality indicator of wheat grain;

$Q_{i, j}-\mathrm{j}$-th indicator of the quality of the $\mathrm{i}$-th grain sample

$n$ - number of grain samples;

$S_{j}-$ standard (mean) deviation of the $\mathrm{j}$-th grain quality indicator;

$V_{j}-$ coefficient of variation of the $\mathrm{j}$-th grain quality indicator;

$R_{j k}$ - correlation coefficient between $\mathrm{j}$-th and k-th indicators of grain quality;

$\bar{Q}_{i, j}$ - the arithmetic mean of the j-th quality indicator of the i-th sample of wheat grain;

$\bar{Q}_{i, k}$ - the arithmetic mean of the k-th quality indicator of the $\mathrm{i}$-th sample of wheat grain.

Isolation and study of the fractional composition of proteins of the gluten complex in 13 samples of wheat grain was carried out under conditions of a relative air humidity of $60 . .75 \%$ and an air temperature of $20 \ldots 22^{\circ} \mathrm{C}$. To isolate 4 fractions of gluten complex proteins (albumins, globulins, gliadins, glutenins, and insoluble proteins of the sediment), wheat grain samples were ground in an LZM-2 mill with a $0.5 \mathrm{MT}$ sieve.

Isolation of protein fractions of wheat grain proteins was carried out by the method proposed by the American researcher T. Osborne [5].

The first combined protein fraction, albumins + globulins, was isolated by protein extraction with $\mathrm{NaCl}$ in a phosphate buffer $(\mathrm{pH}=7.0)$ for at least 12 hours at a temperature of $\mathrm{t}=4^{\circ} \mathrm{C}$, followed by centrifugation for $\tau$ $=15 \mathrm{~min}$. at a temperature of $\mathrm{t} \leq 8^{\circ} \mathrm{C}$ with a rotational speed $\omega=4000 \mathrm{~min}^{-1}$. For the final separation of albumins and globulins, the precipitate was washed 5 times with a 10 -fold volume of cooled extractant $(\mathrm{NaCl}$ in phosphate buffer).

To obtain the second fraction of proteins, the precipitate was poured with cooled distilled water and centrifuged at a temperature of $t \leq 8^{\circ} \mathrm{C}$ for $\tau=10 \mathrm{~min}$. with rotation frequency $\omega=4000 \mathrm{~min}^{-1}$. A 2-fold volume of $65 \%$ ethanol was added to the precipitate. The samples were extracted for 3 hours at room temperature with occasional stirring. After extraction, centrifugation was carried out at room temperature $\tau=15 \mathrm{~min}$. with a rotational speed $\omega=4000 \mathrm{~min}^{-1}$. The supernatant contains the necessary fraction, gliadin.

To isolate the third fraction, glutenins, the following operations were performed. After the isolation of gliadins, a 3 -fold volume of $0.05 \mathrm{~N} \mathrm{NaOH}$ was added to the sediment and extraction was performed for $\tau=30$ min. at $\mathrm{t} \leq 8^{\circ} \mathrm{C}$ with rotation frequency $\omega=4000 \mathrm{~min}^{-1}$. After centrifugation, $0.1 \mathrm{~N}$ acetic acid was added to the formed precipitate and centrifuged again. The resulting sediment contained the protein fraction, glutenin, necessary for further research.

The extracts of 4 protein fractions obtained in this way were used for separation by electrophoresis into structures separate by molecular weights.

Preparation of samples for entering into electrophoretic chambers consisted in bringing the concentration of protein samples (mini-samples) to concentrations $\mathrm{C}=1 \mathrm{~mol} / \mathrm{l}$ and adding a dye - silver oxide. Protein concentration was measured using the Warburg method on a spectrophotometer. To determine the amount of protein, the absorbance of the solution was measured at $260 \mathrm{~nm}$ and $280 \mathrm{~nm}$. Measurements at 260 $\mathrm{nm}$ made it possible to calculate the protein concentration in the sample. The $260 \mathrm{~nm} / 280 \mathrm{~nm}$ ratio made it possible to draw conclusions about the purity of the protein preparation.

For electrophoresis, a vertical electrophoretic chamber was assembled. At the bottom of the chamber, solution No. 1 was poured to ensure its tightness along the lower edge. On top of the solution No1 was poured solution No. 2 - a separating polyacrylamide gel, and, then, the third layer - a concentrating gel - solution No. 3 .

\section{Composition of solutions:}

No. $1-30 \%$ acrylamide + ammonium pyrosulfate + TEMED (tetramethylethylenediamine)

No. 2 - tris buffer + acrylamide + ammonium pyrosulfate + TEMED;

No. 3 - buffer $+30 \%$ acrylamide $+10 \%$ ammonium pyrosulfate + TEMED.

After entering the gels into the electrophoretic chamber, a "comb" is inserted and remains in the chamber for 48 hours, until the gels completely solidify. Further, prepared protein samples and markers were introduced into each of the obtained cells after the "comb" to identify separated protein structures with different molecular weights. The electrophoretic separation process takes place during 12:00 at a current strength of $\mathrm{I}=100 \mathrm{~mA}$, after which the obtained gel electrophoretic patterns are developed and illuminated and analyzed.

\section{Research results}

At the first stage of research, using the described methods, the main indicators of the quality of wheat grain samples selected for research were determined, their classes were determined. The results obtained, grouped by class and sorted within the classes in ascending protein, are shown in table. 1 . The same table shows the following statistical characteristics of quality indicators as arithmetic mean (arithmetical mean), Standard or mean deviation (st. deviation. Sj) and coefficient of variation (coef. var. V) [13-15].

As it can be noticed, the moisture content of all 
wheat samples was in the range of $9.4 \ldots 13.5 \%$, that is, did not exceed the standard values of $14.0 \%$.

The bulk density was $731 \ldots 814 \mathrm{~g} / 1$ with an arithmetic mean of $772 \mathrm{~g} / \mathrm{l}$, which exceeds the value of $750 \mathrm{~g} / 1$ normalized for class 2 wheat.

The protein content in the studied samples was in the range of $10.1 \ldots 13.2 \%$. Naturally, less protein was contained in the samples of class 6 wheat (non-food), and most of all - in samples of class 2 wheat, especially in the sample of wheat of the "Chernobrova" variety (No. 4). According to the arithmetic mean of the protein content in all studied samples $(11.9 \%)$, wheat can be attributed to this indicator to the $3 \mathrm{rd}$ class $(\geq 11.0 \%)$.

The gluten content ranged from $16.4 \%$ to $25.6 \%$. It can be noted that according to this indicator, two samples of 9 and 10 wheat of the 5th class and the sample of 13 wheat of the 6th class met the requirements of wheat of the 2 nd class ( $\geq 23 \%$ ).

The quality of gluten, determined in conventional units of the IDK device, in almost all samples, except for 9 and 11 (5th class) and 13 (6th class), met the requirements of class 2 wheat $(45 \ldots 100$ units of the VDK device).

The falling number of all samples (harvest 2016) was high $(311 \ldots 493 \mathrm{~s})$ and significantly exceeded the normalized value (180 s) even for class 2 wheat.

The content of grain impurities was in the range $-1.2 \ldots 10.5 \%$. For individual classes, the normalized values of the content of grain impurities are (no more): for the 2 nd and 3 rd classes $8 \%$, for the 5 th class $12 \%$, for the 6th class $15 \%$. As can be seen, all samples corresponded to the normalized boundaries in terms of the grain impurity content.

The content of grains damaged by the wheat bug varied within wide limits from $0.1 \%$ to $10.1 \%$. There were no specimens that were not affected by the wheat bug. The indicator is not class-forming.
At the second stage of the research, the values of the coefficients of variation were calculated and the uniformity of the distribution of individual indicators of the quality of wheat grain in the studied 13 samples from different enterprises in the south of Ukraine was assessed. The analysis of the obtained results, using the conditional gradations recommended in [14], showed that such indicators of grain quality as moisture, bulk density and protein content in different samples of southern Ukraine fluctuate weakly ( $\leq 10 \%$ ), fluctuations of the amount of gluten and the falling number are average $(10 \% \leq \mathrm{V} \leq 20 \%)$, while fluctuations in the content of grain impurities and grains damaged by the wheat bug are big $(\mathrm{V} \geq 20 \%)$. For the latter indicator, the fluctuations relative to the average are very big and exceed $120 \%$. This indicates that in different areas where wheat was grown, the infestation by the wheat bug was very different.

It should also be noted that there is an average correlation between the content of gluten and protein in

Number of grain sample

$\begin{array}{llllllllllllll}1 & 2 & 3 & 4 & 5 & 6 & 7 & 8 & 9 & 10 & 11 & 12 & 13\end{array}$

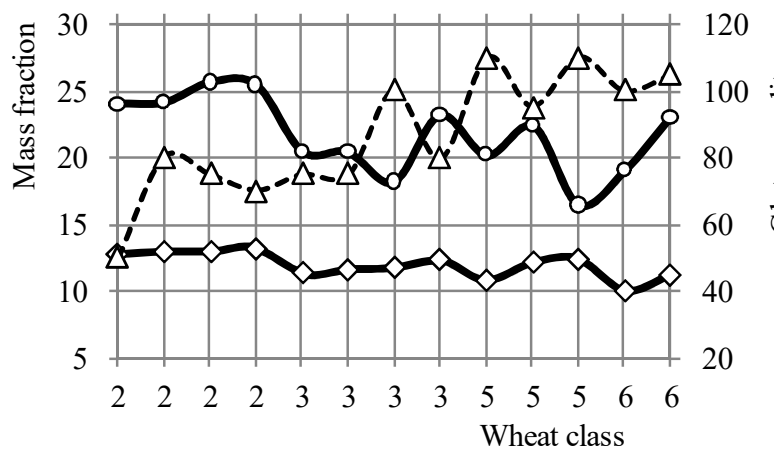

$\leadsto$ Protein $\longrightarrow$ Gluten content $--\Delta--$ Gluten quality

Figure 1 - Dependence of the content of protein and gluten and its quality on the class of wheat in the 13 studied samples

Table 1 - Main indicators of the quality of wheat samples selected for research

\begin{tabular}{|c|c|c|c|c|c|c|c|c|c|}
\hline \multirow[t]{2}{*}{ Sample number } & \multirow[t]{2}{*}{ Class } & \multirow{2}{*}{$\begin{array}{c}\text { Moistu } \\
\text { re } \\
\text { conten } \\
\text { t, \% } \\
\end{array}$} & \multirow{2}{*}{$\begin{array}{c}\text { Bulk } \\
\text { density, } \\
\mathrm{g} / \mathrm{l}\end{array}$} & \multirow{2}{*}{$\begin{array}{c}\text { Protein } \\
\text { content, } \\
\%\end{array}$} & \multicolumn{2}{|c|}{ Gluten } & \multirow{2}{*}{$\begin{array}{c}\text { Falling } \\
\text { number, } \mathrm{s}\end{array}$} & \multirow{2}{*}{$\begin{array}{c}\text { Grain } \\
\text { impurities, } \\
\%\end{array}$} & \multirow{2}{*}{$\begin{array}{c}\text { Grain, } \\
\text { damaged by } \\
\text { wheat bug, } \\
\% \\
\end{array}$} \\
\hline & & & & & $\begin{array}{c}\text { content, } \\
\%\end{array}$ & $\begin{array}{l}\text { quality, unit } \\
\text { device VDK, }\end{array}$ & & & \\
\hline 1 & 2 & 10,9 & 773 & 12,7 & 24,0 & 50 & 420 & 7,6 & 1,3 \\
\hline 2 & 2 & 11,2 & 781 & 12,9 & 24,1 & 80 & 459 & 5,6 & 2,0 \\
\hline 3 & 2 & 11,3 & 802 & 12,9 & 25,6 & 75 & 426 & 4,6 & 0,5 \\
\hline 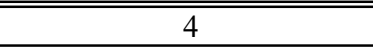 & 2 & $9,9,4$ & 795 & 13,2 & 25,4 & 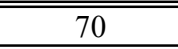 & 365 & $1 \overline{1,2}$ & 0,1 \\
\hline 5 & 3 & 12,1 & 783 & 11,3 & 20,4 & 75 & 493 & 4,4 & 1,9 \\
\hline 6 & 3 & 12,4 & 774 & 11,6 & 20,4 & 75 & 456 & 4,8 & 0,8 \\
\hline 7 & 3 & 12,6 & 758 & 11,7 & 18,2 & 100 & 417 & 6,9 & 1,5 \\
\hline 8 & 3 & 11,4 & 779 & 12,3 & 23,2 & 80 & 484 & 7,3 & 1,1 \\
\hline 9 & 5 & 11,4 & 814 & 10,8 & 20,2 & 110 & 311 & 3,2 & 3,8 \\
\hline 10 & 5 & 13,2 & 733 & 12,1 & 22,4 & 95 & 357 & 8,0 & 1,7 \\
\hline 11 & 5 & 13,5 & 734 & 12,4 & 16,4 & 110 & 403 & 10,5 & 10,1 \\
\hline 12 & 6 & 12,6 & 731 & 10,1 & 19,0 & 100 & 372 & 5,5 & 0,5 \\
\hline 13 & 6 & 12,1 & 780 & 11,2 & 23,0 & 105 & 354 & $6,6^{*}$ & 2,6 \\
\hline Arithmetic mean. $\bar{Q}_{j}$ & & 11,8 & 772 & 11,9 & 21,7 & 87 & 409 & 5,3 & 2,1 \\
\hline Standard deviation $S_{j}$ & & 1,1 & 26 & 0,9 & 2,8 & 18 & 55 & 2,4 & 2,6 \\
\hline Coefficient of variation $V, \%$ & & 9,1 & 3,4 & 7,7 & 13,1 & 21 & 13 & 45,8 & 120,4 \\
\hline
\end{tabular}

Notes: * In the grain impurity of sample 13 there was $7 \%$ barley. 


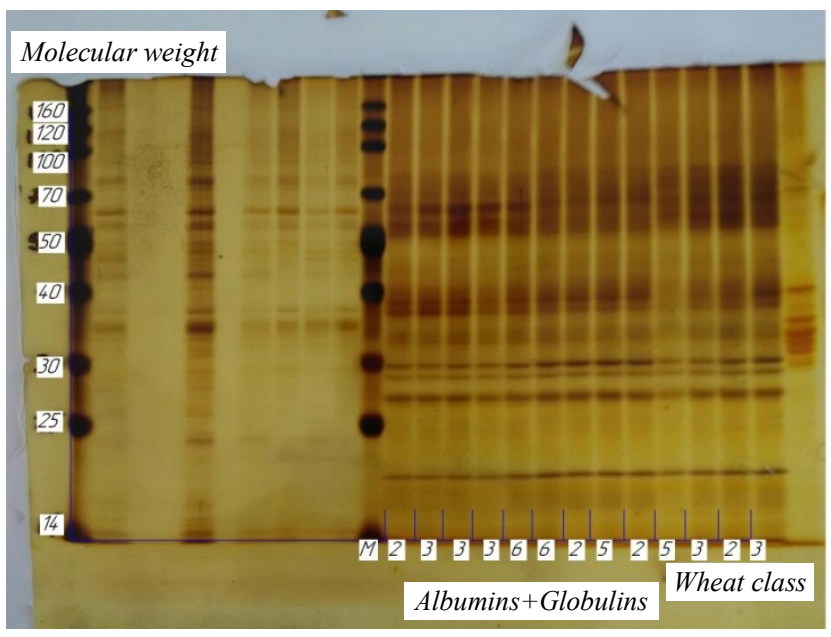

a) albumins + globulins

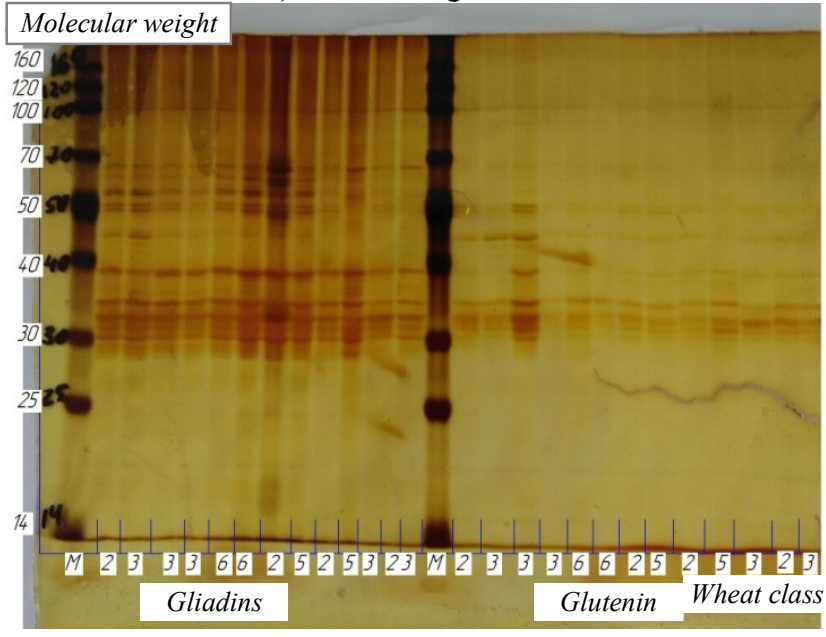

b) gliadins and glutenins

\section{Figure 2 - Gel electropherograms of wheat protein fractions of different classes ( $M$ - markers)}

the studied samples of wheat grain - the correlation coefficient between them is 0.59 [15]. A visual view of the dependence of the protein and gluten content and its quality on the class of wheat in the studied 13 wheat samples from the southern regions of Ukraine, harvest 2016, are shown in Figure 1.

At the last stage of the research, the proteins of the gluten complex - albumins, globulins, gliadins, glutenins - were investigated in more details. According to the Osborne method described above, fractionation of proteins was carried out in 13 samples of wheat grain selected for research. The obtained gel electrophoregrams are shown in Figure 2. On the first of them (Figure 2-a) on the left it can be seen the labels of the marker $\mathrm{M}$ separated by molecular weights (value in kDa: 14, 25, 40, 50, 70, 100, 120 and 160). Further, it can be seen that the labels of individual structures of 13 protein samples, albumins+globulins, were separated by electrophoresis (according to the number of wheat samples of different classes).

On the second electropherogram (Fig. 2-b), one can see sequentially from left to right, the labels of the $M$ marker and the labels of individual structures of 13 gliadin protein samples (according to the number of wheat samples of different classes) are divided by molecular weights. The following shows, in the same sequence, the $\mathrm{M}$ marker and individual structures of 13 glutenin protein samples.

The analysis of the gel electrophoregrams showed the following.

Proteins with molecular weights of $20 \mathrm{kDa}, 27$ $\mathrm{kDa}, 29 \mathrm{kDa}, 30 \mathrm{kDa}$ are clearly distinguished in the combined fractions of albumins and globulins in all samples. In particular, it is observed that in the sample of varietal wheat "Chernobrova" (No. 4), albumins and globulins have a higher molecular weight than in nonvarietal wheat, namely, they fluctuate within the range of $30 \ldots 40 \mathrm{kDa}$. In addition, high-molecular-weight proteins with a molecular weight of $70 \mathrm{kDa}$ are present in varietal wheat. And since albumins and globulins affect enzymatic activity, based on the data obtained, it can be concluded that the quality of albumin and globulin proteins affects varietal resistance, that is, the invariability of the qualitative composition of wheat during storage.

In the studied samples of wheat grain, a significantly larger amount of the gliadin fraction is observed in comparison with other protein fractions. Thus, the bulk of proteins fall within the ranges of $28 \ldots 40 \mathrm{kDa}$ and $50 \ldots 70 \mathrm{kDa}$, and the molecular weight of gliadins ranges from $27 \ldots 100 \mathrm{kDa}$.

The fraction of glutenins is more clearly appeared in the range of $30 \ldots 35 \mathrm{kDa}$.

Regardless of the total amount of protein determined by the Infratec FOSS express analyzer, it can be concluded that four protein fractions of the gluten complex are present in all grain classes, and the molecular weights of the protein fractions vary within small limits.

Thus, using gel electrophoresis, it was possible to reveal the presence of certain fractions of proteins, as well as to determine the molecular weights of their individual structures.

\section{Conclusions}

1. Wheat grain from the southern regions of Ukraine in 2016 had the following quality indicators: moisture content $9.4 \ldots 13.5 \%$, bulk density $731 \ldots 814$ $\mathrm{g} / \mathrm{l}$, protein content $10.1 \ldots 13.2 \%$, gluten content $16.4 . .25 .6 \%$, gluten quality $50 \ldots 110$ units of the IDK device, falling number $311 \ldots 493 \mathrm{~s}$, grain admixture $1.2 \ldots 10.5 \%$, grains damaged by a wheat bug , $0.1 \ldots 10.1 \%$. It can be noted that the bulk density of all samples of wheat of 2 ...6 classes exceeded the standard values in each class. In terms of protein content, 2 from 3 samples of class 5 wheat and 1 from 2 samples of 6 class exceeded the standard value of class 3 wheat $(\geq 11.0 \%)$. The same was observed for these samples and for the gluten content $(\geq 18 \%)$. Almost all grain samples, except for 2 samples of the 5 th class and 2 samples of the 6th class, met the requirements of wheat of the 2 nd class (45...100 units VDK device). The falling number of all samples was high and significantly exceeded the normalized value (180 s), even for class 2 wheat.

2. It was found that the uniformity of the distribution of individual quality indicators in different classes of wheat grain by the coefficient of variation is not the same. Such indicators of grain quality as moisture 
content, bulk density and protein content in different samples of the south of Ukraine in 2016 harvest fluctuated weakly $(\mathrm{V} \leq 10 \%)$, in terms of the amount of gluten and the falling number fluctuations were average $(10 \% \leq \mathrm{V} \leq 20 \%)$. Fluctuations in the content of grain impurities and grains damaged by the wheat bug are big ( $\mathrm{V} \geq 20 \%$ ). For the final indicator, the fluctuations relative to the average are very large and exceed $120 \%$. This indicates that in different areas where wheat was grown, the infestation by the wheat bug was very different.

3 . It has been shown that regardless of the total amount of protein content determined by the Infratec
FOSS express analyzer, four protein fractions of the gluten complex (albumins, globulins, gliadins and glutenins) are present in all grain classes, and the molecular weights of the protein structures of the main fractions are within small limits, which are in $\mathrm{kDa}-$ for albumins and globulins 20...30, gliadins $27 \ldots 100$ and glutenins $30 \ldots 35$. It is noted that in the varietal wheat "Chernobrova" albumins and globulins have a slightly higher molecular weight $(30 \ldots 40 \mathrm{kDa})$ than in nonvarietal wheat.

\section{REFERENCES}

1. Yakisne i kilkisne vyznachennia bilka. StudFiles. URL: https://studfiles.net/preview/5456611/page:4/ (data zvernennia 07.06.2018)

2. Prylady dlia vyznachennia bilka (azotu) metodom Diuma - NDA 701/702. https://soctrade.ua/ obladnannya/katalog/nda-701702/

3. Kharakterystyka suchasnykh metodiv vyznachennia syroho proteinu $\square$ u kormakh ta roslynnii syrovyni / H.V. Kushnir, T.R. Levytskyi, H.P. Ryvak ta in. URL : https://core.ac.uk/download/pdf/235835284.pdf (data zvernennia 08.12.2020)

4. Kozmyna N.P. Byokhymyia zerna y produktov eho pererabotky. M.: Kolos, 1976. 375 s.

5. Rybalka O.I. Yakist pshenytsi ta yii polipshennia. K.: Lohos, 2011. 496 s.

6. Humeniuk O.L. Kharchova khimiia. Rozdilennia bilkiv pshenytsi na okremi fraktsii v zalezhnosti vid rozchynnosti. URL : https://cpo.stu.cn.ua/Oksana/harch_himia_lab_prakt/120.html (data zvernennia: 07.06.2018)

7. Morel M., Dehlon P., Autran J.C. et al. Effect of temperature, sonication time and power settings on size distribution and extractability of total wheat proteins as determined by size-exclusion high performance liquid chromatography. Cereal Chem. 2000. 77, N 5. P. 685-691

8. Larchenko K.A., Morhun B.V. Oznaky yakosti zerna pshenytsi ta metody yikh polipshennia // Fyzyolohyia y byokhymyia kulturnblkh rastenyi. 2010. T. 42. №6. S. 463-474.

9. Hel-elektroforez. Vikipediia. URL: https://uk.wikipedia.org/wiki/Hel-elektroforez (data zvernennia 07.06.2018)

10. Sravnenye pokazatelei kachestva zerna Ukraynbl, SShA y ES // Informatsiina kompaniia «ProAhro Hrup». 2020 yanv. URL: http://www.proagro.com.ua/reference/standard/usstand/11021.html (data zvernennia 8.12.2020).

11. Poshkodzhene $i$ nepovnotsinne zerno ta yoho vykorystannia. URL: https://propozitsiya.com/ua/poshkodzhene-inepovnocinne-zerno-ta-yogo-vikoristannya (data zvernennia 22.03.2019).

12. Nuzhno ly povbishat kachestvo ukraynskoho zerna? URL: https://propozitsiya.com/chy-potribno-pidvyshchuvaty-yakistukrayinskogo-zerna (data zvernennia 13.11.2019).

13. Kobuta I., Sikachyna O., Zhygadl V. Wheat export economyin Ukraine. Policy Studies on Rural Transition. No. 2012-4. URL: https://www.academia.edu/38045999/WHEAT_EXPORT_ECONOMY_IN_UKRAINE (дата звернення 8.12.2020).

14. Koeffitsiyent variatsii: formula $i$ raschet $v$ Excel $i$ interpretatsiya rezultatov. URL: https://exceltable.com/ otchety/koefficient-variacii (data zvernennya 8.12.2020).

15. Koeffitsiyent variatsii: formula $i$ raschet $v$ Excel $i$ interpretatsiya rezultatov. URL: https://exceltable.com/ otchety/koefficient-variacii (data zvernennya 8.12.2020).

16. Koeffitsiyenty korrelyatsii. URL: http://www.datuapstrade.lv/rus/spss/section_11/4/(data zvernennya 8.12.2020).

\section{УДК: 633.39:582.663.2:631.562}

${ }^{\mathbf{1}}$ А.А. Пенаки, заст. завідувача лабораторії ${ }^{1}$, E-mail: annarevenko28041987@gmail.com ${ }^{2}$ A.B. Борта, канд. техн. нау., доцент ${ }^{2}, E$-mail: borta.alla@ukr.net ${ }^{1}$ ТОВ «М.В.Карго», вул. Олексія Ставніџера, 60, село Візирка, Одеська обл., Украӥна 67543 ${ }^{2}$ Одеська начіональна академія харчових технологій, вул. Канатна, 112, м. Одеса, Украӥна, 65039

\section{ДОСЛІДЖЕННЯ ПОКАЗНИКІВ ЯКОСТІ ТА ФРАКЦЙНОГО СКЛАДУ БІЛКА ЗЕРНА ПШЕНИЦІ ПІВДЕННИХ РЕГІОНІВ УКРАЇНИ}

\footnotetext{
Анотація

Наведено результати досліджень якості продовольчого та непродовольчого зерна пшениці з південних регіонів України 2016 року врожаю. Визначено показники якості зерна пшениці, проведено оцінку однорідностіїх розподілу у різних класах пшенииі, визначено вміст білкових фракиій клейковинного комплексу та молекулярні маси окремих білкових структур.Встановлено, що досліджені 13 зразків зерна пшеничі мали такі показники якості: вологість 9,4 ..13,5\%, натура $731 \ldots 814$ г/л, вміст білка 10,1 ..13,2\%, вміст клейковини 16,4... $25,6 \%$, якість клейковини $50 \ldots 110$ одинииь приладу ВДК, число падіння $311 \ldots 493$ с, зернова домішка 1,2.. $10,5 \%$, зерна, пошкоджені клопом-черепашкою, 0,1 ..10,1\%. Відмічено, що натура у всіх зразках пшенииі $2 \ldots 6$ класів перевищувала нормативні значення у кожному класі. За вмістом білка 2 iз 3-х зразків пшениџі 5 класу та 1 із 2-х зразків 6 класу перевищували нормативне значення пшенииі 3 класу $(\geq 11,0 \%$ ). Це ж спостерігалось для иих же зразків і для вмісту клейковини ( $\geq 18 \%$ ). Практично всі зразки зерна, крім 2-х зразків 5-го класу та 2-х
} 
зразків 6-го класу, задовольняли вимогам пшениці 2 класу (45...100 од. прил. ВДК). Число падіння всіх зразків було високим та значно перевищувало нормоване значення (180 c), навіть для пшениці 2 класу.Встановлено, щзо однорідність розподілу окремих показників якості у різних класах зерна пшениці за коефіцієнтом варіації неоднакова. Такі показники якості зерна як вологість, натура та вміст білка у різних зразках півдня України 2016 року врожаю коливались слабо ( $V \leq 10 \%)$, за кількістю клейковини та число падіння коливання були середніми $(10 \% \leq V \leq 20 \%)$. Коливання ж вмісту зернової домішки та зерен, пошкоджених клопом черепашкою, є сильними $(V \geq 20 \%)$. Для останнього показника коливання відносно середнього значення є дуже великими $і$ перевищують $120 \%$ Ц Це свідчить про те, що на різних площчах, де вирощували пшеницю, ураженість клопомчерепашкою була дуже різною.Показано, що незалежно від загальної кількості білка, визначеної експресаналізатором Infratec FOSS, чотири білкові фракиї клейковинного комплексу (альбуміни, глобуліни, гліадіни та глютеніни) присутні у всіх класах зерна, а молекулярні маси білкових структур основних фракцій знаходяться у невеликих межах, які складають у кДа - для альбумінів і глобулінів 20...30, гліадинів $27 . .100$ та глютенінів 30...35. Відмічено щуо у сортовій пшениці «Чорноброва» альбуміни і глобуліни мають дещо вищу молекулярну масу (30...40 кДа), ніж у несортовій пшениці.

Ключові слова: зерно, класи пшениці, показники якості пшениці, білки, гель-електрофорез, фракційний склад білків, молекулярні маси.

\section{ЛITEPАТУРА}

1. Якісне і кількісне визначення білка. StudFiles.URL: https://studfiles.net/preview/5456611/page:4/(дата звернення 07.06.2018)

2. Прилади для визначення білка (азоту) методом Дюма - NDA 701/702. https://soctrade.ua/ obladnannya/katalog/nda-701702/ (дата звернення 08.12.2020)

3. Характеристика сучасних методів визначення сирого протеїнуу кормах та рослинній сировині / Г.В. Кушнір, Т.Р. Левицький, Г.П. Ривак та ін. URL : https://core.ac.uk/download/pdf/235835284.pdf(дата звернення 08.12.2020)

4. Козьмина Н.П. Биохимия зерна и продуктов его переработки. М.: Колос, 1976. 375 с.

5. Рибалка О.І. Якість пшениці та ї̈ поліпшення. К.: Логос, 2011. 496 с.

6. Гуменюк О.Л. Харчова хімія. Розділення білків пшениці на окремі фракиії в залежності від розчинності.URL: https://cpo.stu.cn.ua/Oksana/harch_himia_lab_prakt/120.html (дата звернення: 07.06.2018)

7. Morel M., Dehlon P., Autran J.C. et al. Effect of temperature, sonication time and power settings on size distribution and extractability of total wheat proteins as determined by size-exclusion high performance liquid chromatography. Cereal Chem. 2000. 77, N 5. P. 685-691

8. Ларченко К.А., Моргун Б.В. Ознаки якості зерна пшениці та методи їх поліпшення // Физиология и биохимия культурных растений. 2010. T. 42. №6. С. 463-474.

9. Гель-електрофорез. Вікіпедія. URL: https://uk.wikipedia.org/wiki/Гель-електрофорез (дата звернення 07.06.2018)

10. Сравнение показателей качества зерна Украины, США и ЕС // Інформаційна компанія «ПроАгро Груп». 2020 янв. URL: http://www.proagro.com.ua/reference/standard/usstand/11021.html(дата звернення 8.12.2020).

11. Поикоджене $i$ неповноцінне зерно та його використання. URL: https://propozitsiya.com/ual poshkodzhene-i-nepovnocinne-zerno-ta-yogo-vikoristannya (дата звернення 22.03.2019).

12. Нужно ли повышать качество украинского зерна? URL: https://propozitsiya.com/chy-potribno-pidvyshchuvatyyakist-ukrayinskogo-zerna (дата звернення 13.11.2019).

13. Kobuta I., Sikachyna O., ZhygadlV. Wheat export economyin Ukraine. PolicyStudies on Rural Transition. No. 20124. URL: https://www.academia.edu/38045999/WHEAT_EXPORT_ECONOMY_IN_UKRAINE (дата звернення 8.12.2020).

14. Коэффициент вариачии: формула $u$ расчет в Excel $u$ интерпретация результатов. URL:https://exceltable.com/otchety/koefficient-variacii(дата звернення 8.12.2020).

15. Коэффициент вариации. URL : http://statistica.ru/glossary/general/koeffitsient-variatsii/

16. Коэффиџиенты корреляции. URL: http://www.datuapstrade.lv/rus/spss/section_11/4/(дата звернення 8.12.2020).

Received 09.08.2020

Reviewed 17.09.2020 $\begin{array}{ll}\text { Revised } & \mathbf{1 3 . 1 0 . 2 0 2 0} \\ \text { Approved } & \mathbf{0 1 . 1 2 . 2 0 2 0}\end{array}$

\section{Cite as Vancouver Citation Style}

Penaki A., Borta A. The study of quality indicators and fractional composition of wheat grain protein of southern regions of ukraine. Grain Products and Mixed Fodder's, 2020; 20 (4, 80): 4-10. DOI

\section{Cite as State Standard of Ukraine 8302:2015}

The study of quality indicators and fractional composition of wheat grain protein of southern regions of ukraine / Penaki A. et al. // Grain Products and Mixed Fodder's. 2020. Vol. 20, Issue 4 (80). P. 4-10. DOI 